\title{
ULTRASTRUCTURE OF THE MIDGUT ENDOCRINE CELLS IN Melipona quadrifasciata anthidioides (HYMENOPTERA, APIDAE)
}

\author{
NEVES, C. A., ${ }^{1,3}$ GITIRANA, L. B. ${ }^{2}$ and SERRÃO, J. E. ${ }^{3}$ \\ ${ }^{1}$ Programa de Pós-graduação em Morfologia, Universidade Federal do Rio de Janeiro \\ ${ }^{2}$ Departamento de Histologia e Embriologia, Universidade Federal do Rio de Janeiro, Cidade Universitária, \\ Ilha do Fundão, CEP 21941-590, Rio de Janeiro, RJ, Brazil \\ ${ }^{3}$ Departamento de Biologia Geral, CCBS, Universidade Federal de Viçosa, CEP 36570-000, Viçosa, MG, Brazil \\ Correspondence to: José Eduardo Serrão, Departamento de Biologia Geral, Universidade Federal de Viçosa, \\ CEP 36570-000, Viçosa, MG, Brazil, e-mail: jeserrao@mail.ufv.br \\ Received October 1, 2002 - Accepted November 13, 2002 — Distributed November 30, 2003
}

(With 9 figures)

\begin{abstract}
In this study we describe the ultrastructure of the endocrine cells observed in the midgut of M. quadrifasciata anthidioides. This bee has two types of endocrine cells, which are numerous on the posterior midgut region. Cells of the closed type are smaller and have irregular secretory granules with lower electrondensity than those of the open cell type. The open cell type has elongated mitochondria mainly on the basal area, where most of the secretory granules are also found. Besides the secretion granules and mitochondria, endocrine cells in this species have well-developed autophagic vacuoles and Golgi complex elements.
\end{abstract}

Key words: insect midgut, endocrine cells, ultrastructure, secretory granules, stingless bee.

\section{RESUMO}

\section{Ultra-estrutura das células enteroendócrinas do intestino médio de Melipona quadrifasciata anthidioides (Hymenoptera, Apidae)}

Neste estudo descrevemos a ultra-estrutura das células enteroendócrinas observadas no intestino médio de M. quadrifasciata anthidioides, abelha na qual ocorrem dois tipos de células enteroendócrinas, concentradas na região posterior do intestino médio. As células do tipo fechado são menores e possuem grânulos de secreção menos eletrodensos e menos regulares do que as células do tipo aberto. As células do tipo aberto possuem ainda longas mitocôndrias concentradas principalmente na região basal, onde também se concentra a maior parte dos grânulos de secreção. Além dos grânulos de secreção e das mitocôndrias, as células endócrinas nessa espécie possuem grandes vacúolos autofágicos e elementos do complexo de Golgi bem desenvolvidos.

Palavras-chave: intestino médio, células enteroendócrinas, ultra-estrutura, grânulos de secreção, abelhas sem ferrão.

\section{INTRODUCTION}

The midgut endocrine cells of insects are not easily identified under light microscopy by techniques classically used for their detection in vertebrates (Cassier \& Fain-Maurel, 1977; Andriès, 1976; Montuenga et al., 1989; Jimenez \& Gilliam, 1990). However, ultrastructural (Priester, 1971; Andriès, 1976;
Reinhardt, 1976; Cassier \& Fain-Maurel, 1977; Endo \& Nishiitsutsuji-Uwo, 1981; Nishiitsutsuji-Uwo \& Endo, 1981; Endo et al., 1982; Brown et al., 1985; Andriès \& Tramu, 1985; Montuenga et al., 1989; Stoffolano et al., 1989) and immunocytochemical studies have demonstrated the presence of these cells in the midgut epithelium of various insect species (Andriès, 1976; Nishiitsutsuji-Uwo \& Endo, 1981; 
Endo et al., 1982; Andriès \& Tramu, 1984, 1985; Iwanaga et al., 1986; Brown et al., 1986; Glattli et al., 1987; Andriès \& Beauvillain, 1988; Montuenga et al., 1989; Zitnan et al., 1993; An et al., 1998).

Few studies have been done with the use of immunocytochemical techniques on endocrine cells in the digestive system of bees. The presence of these cells was observed in Bombus sp. (Zitnan et al., 1993) and in Melipona quadrifasciata anthidioides (Neves et al., 2002). Raes \& Verbeke (1994) described in details the ultrastructure, ontogeny, and distribution of two types of endocrine cells in Apis mellifera, complementing the brief observations of Jimenez \& Gilliam (1990). Serrão \& Cruz-Landim (1996) described the ultrastructural features of these cells in Trigona spinipes and T. hypogea, two stingless bee species with different feeding habits.

Midgut endocrine cells in insects are characterized by presence of clear cytoplasm, secretory granules mainly in the basal area, cytoplasmic processes reaching the intestinal lumen, and absence of basal plasma membrane infoldings since they are scattered in the base of the digestive cells (Priester, 1971; Brown et al., 1985; Serrão \& Cruz-Landim, 1996). However, some differences in relation to the number, type, and distribution of these cells are observed among the studied species, possibly indicating important differences in the digestive physiology of these insects (Andriès \& Tramu, 1985).

As part of an ongoing study to understand the physiological role of the endocrine cells in the bee midgut, this paper describes the ultrastructure of the endocrine cells observed in the adult worker midgut of Melipona quadrifasciata anthidioides.

\section{MATERIAL AND METHODS}

Eight adult workers of $M$. quadrifasciata anthidioides were analyzed. Bees obtained from nests in the Central Apiary of the Federal University of Viçosa, State of Minas Gerais, Brazil, were immobilized by cold and their digestive tracts removed in saline solution proper for insects $\left(500 \mathrm{ml} \mathrm{H}_{2} \mathrm{O}, 3.75\right.$ g NaCl, $1.36 \mathrm{~g} \mathrm{KH}_{2} \mathrm{PO}_{4}, 1.2 \mathrm{~g} \mathrm{Na}_{2} \mathrm{HPO}_{4}$ ). Midguts were transferred to Karnovsky fixative solution (Bancroft \& Steven, 1996), for $24 \mathrm{~h}$ at $4^{\circ} \mathrm{C}$. Pieces were washed in $0.1 \mathrm{M}$ sodium cacodylate buffer at pH 7.2 and post-fixed in $1 \%$ osmium tetroxide in the same buffer for $1 \mathrm{~h}$. After another washing in the buffer, the pieces were stained in $2 \%$ uranyl acetate for 12 $\mathrm{h}$ at $4^{\circ} \mathrm{C}$, following dehydration in acetone series and embedding in Epon-araldite. Semi-thin sections were stained with $1 \%$ toluidine blue-borax, and ultra-thin ones were stained with lead citrate (Reynolds, 1963), examined, and photographed under a Zeiss EM-109 transmission electron microscope.

\section{RESULTS}

Midgut endocrine cells in M. quadrifasciata anthidioides are restricted to the posterior region of the midgut. In the semi-thin sections, these cells show cytoplasm and nucleus weakly stained, contrasting with the dark digestive cells. It was impossible, however, to distinguish the presence of cytoplasmic granules under lower resolution (Fig. 1). Midgut endocrine cells are smaller than digestive cells and have a more euchromatic nucleus with one or two nucleoli. The endocrine cells were found near the nests of regenerative cells, but never seen inside them, therefore no relationship between them seemed to exist.

The ultrastructural features of these cells allowed recognizing two different cell types that were, according to the classification of Fujita \& Kobayashi (1977), identified as (1) the closed type, whose apex does not reach the midgut lumen, and (2) the open type that has a cytoplasmic prolongation reaching the epithelium apex.

Closed cells have their nucleus in the middleapical portion, where the cytoplasm is scarce, with small mitochondria and few secretory granules. The plasma membrane is smooth and without the extensive basal infoldings found in the neighboring digestive cells (Figs. $2,4)$. The basal portion has many secretory granules whose electron density is similar to that of the adjacent cytoplasm. The closed cells observed in this study have slightly oval granules approximately $170 \mathrm{~nm}$ diameter and exhibiting medium eletrondensity, a characteristic that facilitates observation of the secretory granule membrane. Ultrastructural features of the secretory granules are variable, because some have an electronlucent halo with an electrondense core and others are filled, i.e., they are not haloed. In yet others, the contents form clots (Fig. 6). Between the nucleus and the secretory granules are large autophagic vacuoles, small rough endoplasmic reticulum cisternae, and a welldeveloped Golgi apparatus (Fig. 8).

Open cells have a more regular nucleus (Fig. 3 ) and the secretory granules are in the basal area. Although they do not present basal plasma membrane infoldings, some indentations into which the basement membrane projects are observed (Fig. 
5). Mitochondria are larger and more numerous than those observed in the closed cells, and more numerous in the infranuclear zone with the secretory granules, where they are long and parallel to cell axis (Fig. 7).
Size of secretory granule is around $150 \mathrm{~nm}$ and it is filled with more electrondense content. As in the closed cells, there are some autophagic vacuoles (Fig. 7) and Golgi apparatus (Fig. 9).

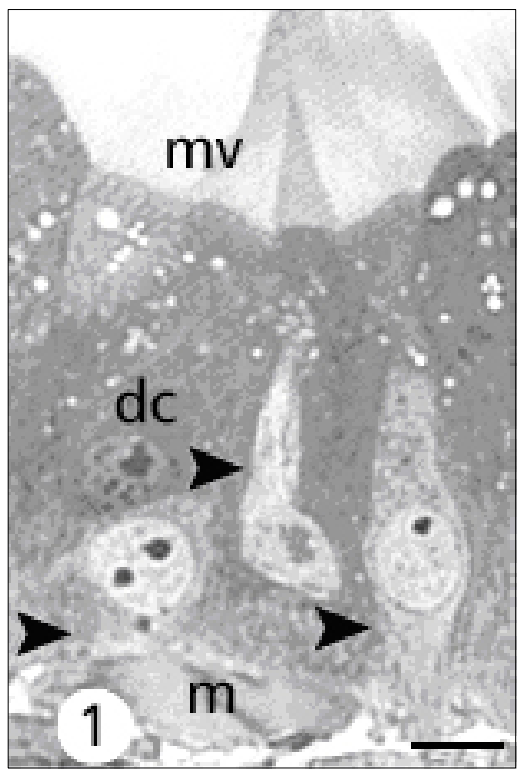

Fig. 1 - Toluidine blue-borax stained semithin sections of the Melipona quadrifasciata anthidioides midgut, showing endocrine cells (arrowheads) and digestive cells (dc). mv: microvilli; m: muscular layer. Bar: $5 \mu \mathrm{m}$.

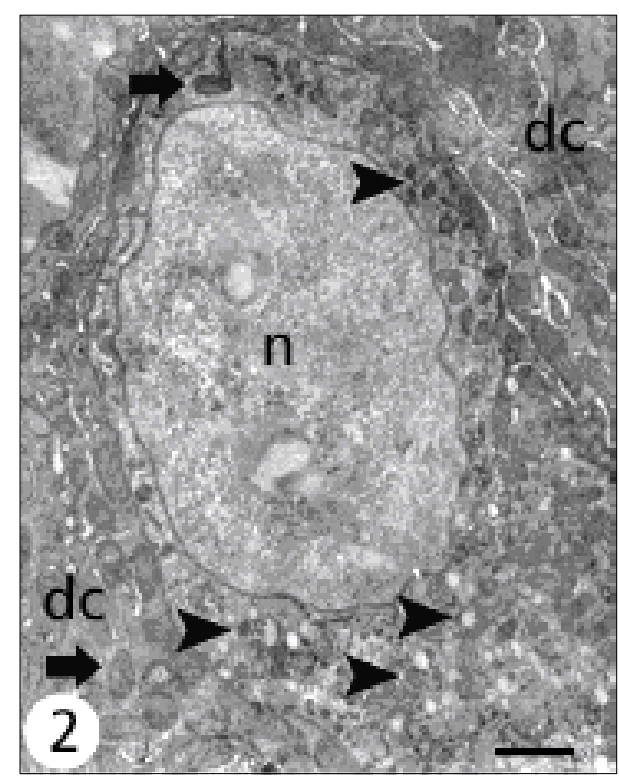

Fig. 2 - Closed-type midgut endocrine cell in Melipona quadrifasciata anthidioides. Notice the nucleus (n) and the basal portion of the cytoplasm replete with secretory granules (arrowheads). Arrows: mitochondria; dc: digestive cells. Bar: $1 \mu \mathrm{m}$. 


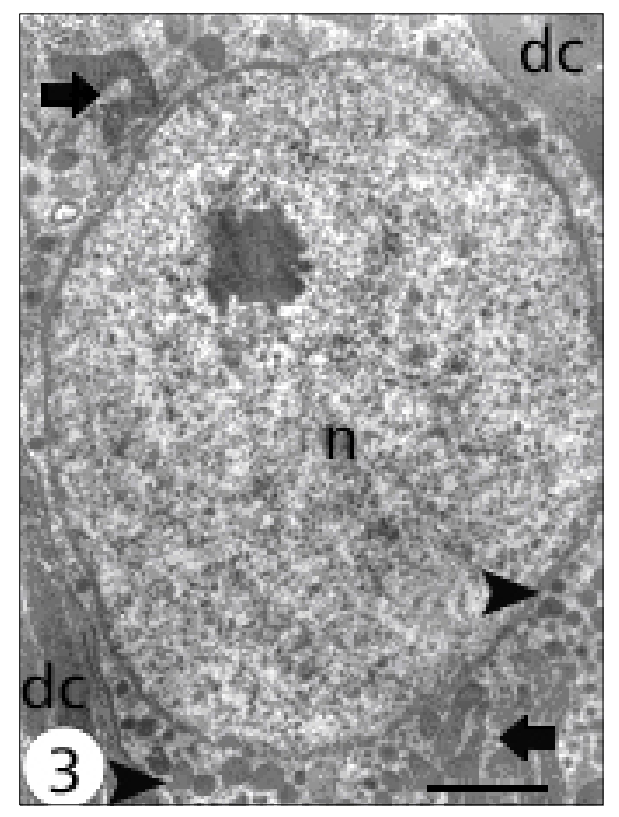

Fig. 3 - Open-type midgut endocrine cell in Melipona quadrifasciata anthidioides. Notice the regular nucleus (n) and the cytoplasm replete with granules (arrowheads) and mitochondria (arrows). dc: digestive cells. Bar: $1 \mu \mathrm{m}$.

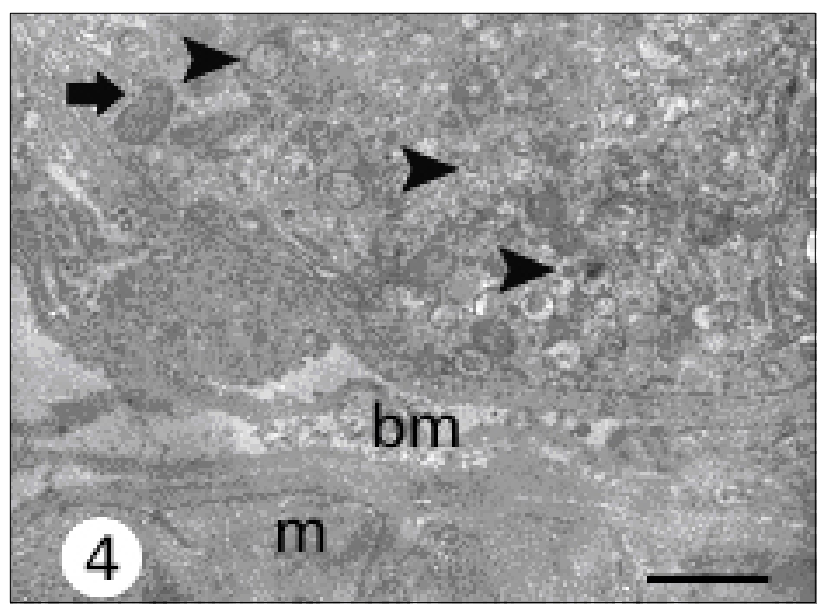

Fig. 4 - Basal portion of the closed midgut endocrine cell of Melipona quadrifasciata anthidioides showing the secretory granules with low electron density (arrowheads) and the absence of basal plasma membrane infoldings and the smooth basement membrane (bm). Arrow: mitochondria; m: muscle. Bar: $1 \mu \mathrm{m}$.

\section{DISCUSSION}

Gut endocrine cells with ultrastructural features similar to those observed in the present study have been described in several insect species. These cells, previously termed granulate cells, were characterized as found in low number, with clearer cytoplasm than that of the digestive cells, electrondense granules, and without basal labyrinth, and are the same as the "probable endocrine cells" described by PlatzerShutltz \& Welsch (1970). Two types of endocrine cells observed in M. quadrifasciata anthidioides have ultrastructural features similar to those described for the larval midgut of Aeshna cyanea. 


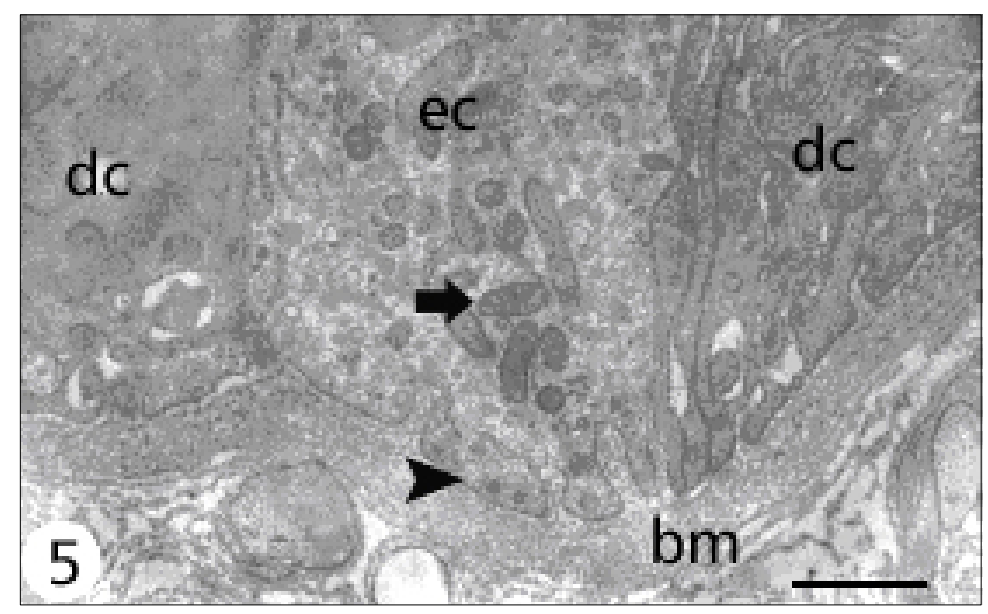

Fig. 5 - Basal area of the open midgut endocrine cell of Melipona quadrifasciata anthidioides showing a great amount of mitochondria (arrow) and the indentation of the basal portion of the cell penetrated by the basement membrane (bm). Arrowhead: secretory granule; dc: digestive cells. Bar: $1 \mu \mathrm{m}$.

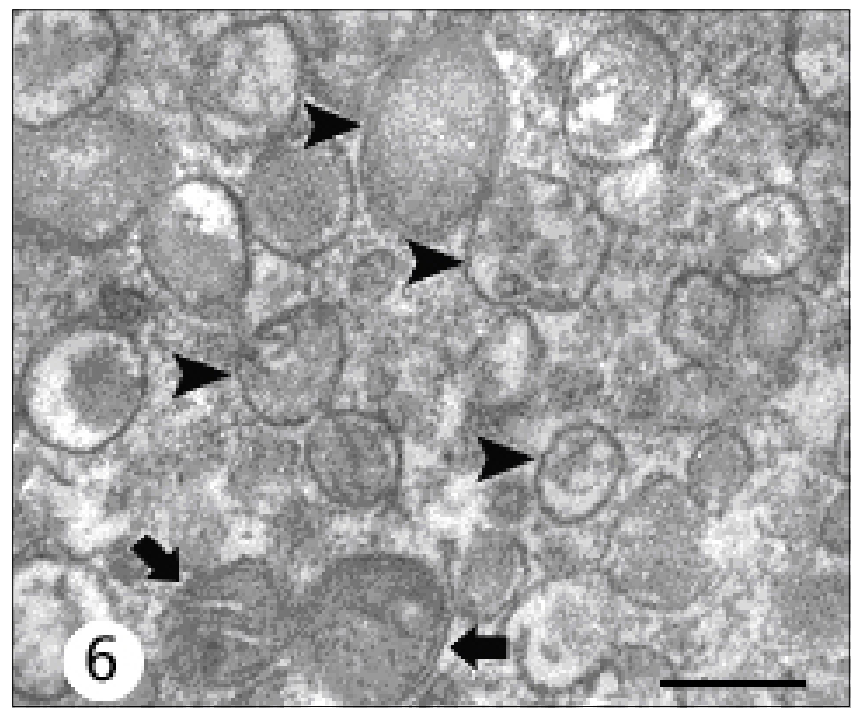

Fig. 6 - Closed midgut endocrine cell of Melipona quadrifasciata anthidioides. Notice that the secretory granule content shows different patterns (arrowheads). Arrows: mitochondria. Bar: $0.2 \mu \mathrm{m}$.

However, in this Odonata species the cells were only of the closed type and the secretory granules were larger (Andriès, 1976). Morphology, size, and electron density of the secretory granules are important characteristics in classifying endocrine cells. Endo \& Nishiitsutsuji-Uwo (1981) found that the most common cells in several Lepidoptera species were those with round, small (100-200 nm), and electrondense secretory granules (Type 3, according to Cassier \& Fain-Maurel,
1977), similar to the cells of the open type found in M. quadrifasciata anthidioides. This was also the only type of endocrine cell observed in three Siphonaptera species (Reinhardt, 1976) and in three other mosquitoe species (Glättli et al., 1987). In Rhodnius prolixus open cells do not occur (Billingsley \& Downe, 1986); these are the predominant type in Schistocerca gregaria (Montuenga et al., 1989). However, the significance of this variation is unknown. 


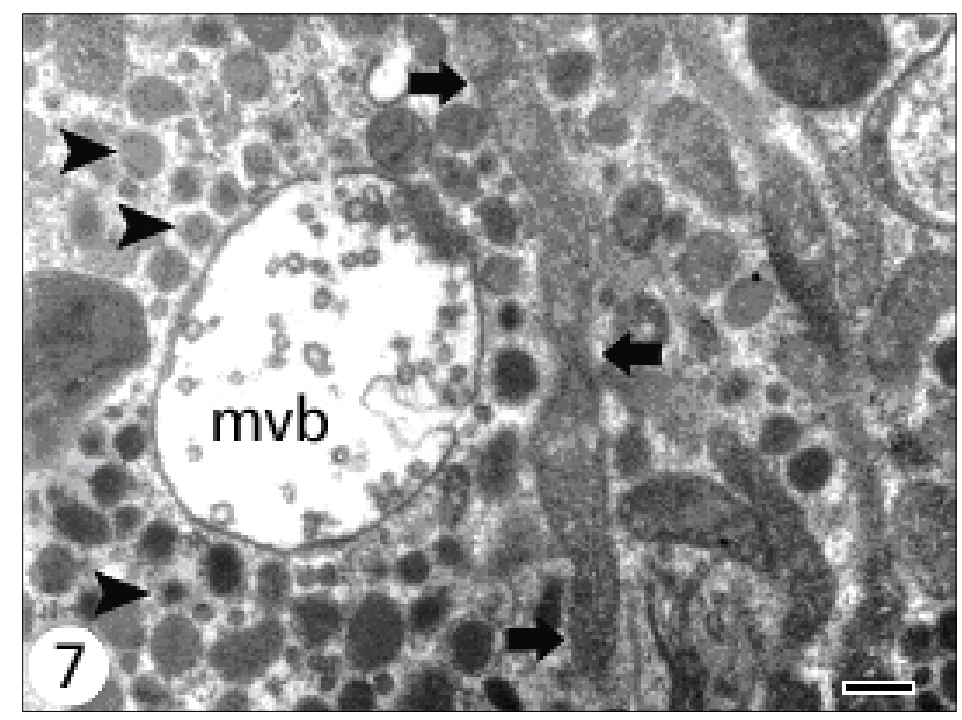

Fig. 7 - Open midgut endocrine cell of Melipona quadrifasciata anthidioides showing electrondense secretory granules (arrowheads), elongated mitochondria (arrows), and a large multivesicular body (mvb). Bar: $0.2 \mu \mathrm{m}$.

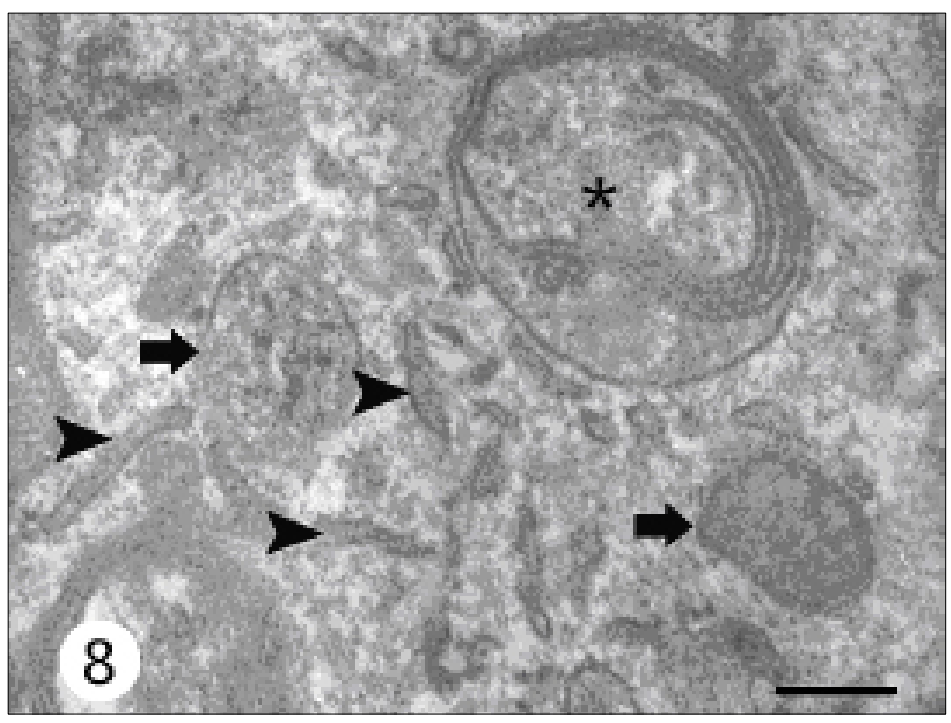

Fig. 8 - Closed midgut endocrine cell of Melipona quadrifasciata anthidioides showing a great autophagic vacuole $(*)$ close to the mitochondria that also presents degeneration signs (arrows) and a modified endoplasmic reticulum cistern (arrowheads). Bar: $0.2 \mu \mathrm{m}$.

Among the Hymenoptera, earlier ultrastructural reports on midgut endocrine cells were limited to a description of a few small pyramidal cells, without basal plasma membrane infolding and with electrondense granules, in the midgut of Apis mellifera (Jimenez \& Gilliam, 1990). Later, still in A. mellifera, two open- endocrine cell types were described in the posterior midgut region. These cells were termed granular cells and contained electrondense granules of 100-200 nm diameter and vesicular cells having large electron lucent vesicles of variable diameter (Raes \& Verbeke, 1994). 


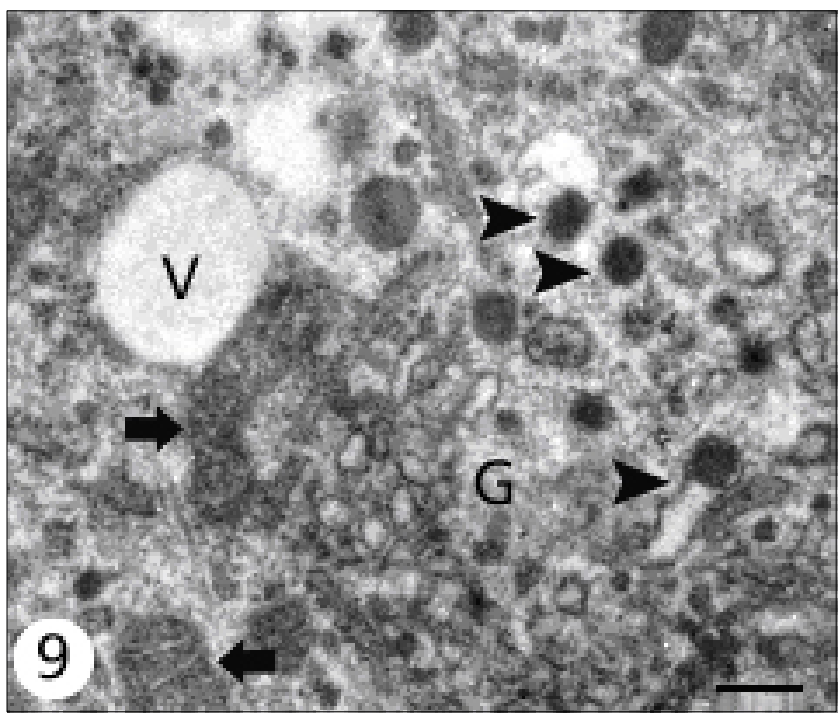

Fig. 9 - Open midgut endocrine cell of Melipona quadrifasciata anthidioides. Notice the secretory granules with electrondense core (arrowheads) close to the Golgi apparatus (G). V: vesicle; arrow: mitochondria. Bar: $0.3 \mu \mathrm{m}$.

Likewise, in two stingless bee species with different feeding habits (Trigona spinipes and $T$. hypogea) only one type of closed midgut endocrine cell was described, without basal labyrinth and with secretory granules accumulated in the basal cell region (Serrão \& Cruz-Landim, 1996). In M. quadrifasciata anthidioides we found two different types of midgut endocrine cells, one common to Hymenoptera species and many other insects studied until now, a the cell with small, electrondense granules. On the other hand, the less electrondense granules found in the closed cells in the present study have not been described in Hymenoptera. The vesicular cells observed in $A$. mellifera (Raes \& Verbeke, 1994) have larger and less electrondense vesicles than the secretory granules found in M. quadrifasciata anthidioides.

Ultrastructural features of the secretory granules in the endocrine cells can be related to the peptide they produce. However, this classification is hindered by morphological variations of these granules as a result of several factors (Grube \& Forssmann, 1979). However, ultrastructural differences among midgut endocrine cells of the same species submitted to the same technical procedure as in the present study may suggest that these cells produce different peptides. In this sense, midgut endocrine cells in M. quadrifasciata anthidioides produce FMRFamide-like, but not cholecystokinin- and gastrin-like peptides (Neves et al., 2002).
Midgut endocrine cells described in this study show a series of ultrastructural characteristics common to the midgut endocrine cells described for insects and exceeding the simple presence of secretory granules. Well-developed Golgi apparatus, large residual bodies in the perinuclear area, and elongated mitochondria are features common to these cells, and should be added to classically recognized others, such as less electrondense cytoplasm and absence of basal infoldings comparable to those of the digestive cells. It is known that midgut endocrine cells produce different peptides and future studies will be conduced to test if there is correlation among the ultrastructural features of secretory granules and the type of secretions produced by these cells in bees.

Acknowledgments - We thank Sonia Oliveira for her skillful technical assistance and Dr. K. Matsuoka for making available the transmission electron microscope used. The Brazilian Research Agencies CNPq, CAPES, FAPEMIG, and FAPERJ supported this work.

\section{REFERENCES}

AN, Y., NAKAJIMA, T. \& SUZUKI, K., 1998, Immunohistochemical demonstration of mammalian- and FMRFamide-like peptides in the gut innervation and endocrine cells of the wild silkmoth, Antheraea yamamai (Lepidoptera: Saturnidae) during diapause and post-diapause of pharate first-instar larvae. Eur. J. Entomol., 95: 185-196. 
ANDRIÈS, J. C., 1976, Presence de deux type cellulaires endocrines et d'un type exocrine au sein du mesenteron de la larve d'Aeshna cyanea Müller (Odonata: Aeshnidae). Int. J. Insect Morphol. Embryol., 5: 393-407.

ANDRIÈS, J. C. \& BEAUVILLAIN, J. C., 1988, Ultrastructural study of cholecystokinin-like immunoreactivity in endocrine cells of the insect midgut. Cell Tissue Res., 254: 75-81.

ANDRIÈS, J. C. \& TRAMU, G., 1984, Détection immunohistoquimique de substances apparentés à des hormones peptidiques de mammifères dans le mesenteron d'Aeshna cynea (Insecte, Odonate). Compte R. Acad. Sc. Paris, 299(6): 181-184.

ANDRIÈS, J. C. \& TRAMU, G., 1985, Ultrastructural and immunohistochemical study of endocrine cells in the midgut of the cockroach Blaberus craniifer (Insecta, Dictyoptera). Cell Tissue Res., 240: 323-332.

BANCROFT, J. D. \& STEVENS, A., 1996, Theory and pratice of histological techniques. 4. ed. Churchill Livingstone, New York, 766p.

BILLINGSLEY, P. F. \& DOWNE, A. E. R., 1986, Nondigestive cell types in the midgut epithelium of Rhodnius prolixus (Hemiptera: Reduviidae). J. Med. Entomol., 23: 212-216.

BROWN, M. R., CRIM, J. W. \& LEA, A. O., 1986, FMRFamideand pancreatic polypeptide-like immunoreactivity of endocrine cells in the midgut of a mosquito. Tissue Cell., 18(3): 419-428.

BROWN, M. R., RAIKHEL, A. S. \& LEA, A. O., 1985, Ultrastructure of midgut endocrine cells in the adult mosquito, Aedes aegypti. Tissue Cell, 17: 709-721.

CASSIER, P. \& FAIN-MAUREL, M. A., 1977, Sur la présence d'un système endocrine diffus dans le mésenteron de quelques insectes. Archs. Zool. Exp. Gén., Paris, 118(2): 197-209.

ENDO, Y. \& NISHIITSUTSUJI-UWO, J., 1981, Gut endocrine cells in insects: the ultrastructure of the gut endocrine cells of the lepidopterous species. Biomedical Research, 2(3): 270-280.

ENDO, Y., NISHIITSUTSUJI-UWO, J., IWANAGA, T. \& FUJTA, T., 1982, Ultrastructural and immunohistochemical identification of pancreatic polypeptide-immunoreactive endocrine cells in the cockroach midgut. Biomedical Research, 3(4): 454-456.

FUJITA, T. \& KOBAYASHI, S., 1977, Structure and function of gut endocrine cells. Int. Rev. Cytol. Suppl., 6: 187-233.

GLATTLI, E., RUDIN, W. \& HECKER, H., 1987, Immunoelectron microscopic demonstration of pancreatic polypeptide in midgut epithelium of hematophagous dipterans. J. Histochem. Cytochem., 35: 891-896.

GRUBE, D. \& FORSSMANN, W. G., 1979, Morphology and function of the entero-endocrine cells. Horm. Metab. Res., 11(11): 589-606.
IWANAGA, T., FUJITA, T., TAKEDA, N., ENDO, Y. \& LEDERIS, K., 1986, Urotensin I-like immunoreactivity in the midgut endocrine cells of the insects Grillus bimaculatus and Periplaneta americana. Cell Tissue Res., 244: 565-568.

JIMENEZ, D. \& GILLIAM, M., 1990, Ultrastructure of the ventriculus of the honey bee, Apis mellifera L.: cytochemichal localization of acid phosphatase, alkaline phosphatase, and non specific esterase. Cell Tiss. Res., 261: 431-443.

MONTUENGA, L. M., BARRENECHEA, M. A., SESMA, P. \& VÁSQUEZ, J. J., 1989, Ultrastructure and immunocytochemistry of endocrine cells in the midgut of desert locust, Schistocerca gregaria (Forskal). Cell Tissue Res., 258: 577-583.

NEVES, C. A., BHERING, L. L., SERRÃO, J. E. \& GITIRANA, L. B., 2002, FMR Famide-like midgut endocrine cells during the metamorphosis in Melipona quadrifasciata anthidioides (Hymenoptera, Apidae). Micron, 33(5): 453-460.

NISHIITSUTSUJI-UWO, J. \& ENDO, Y., 1981, Gut endocrine cells in insects: the ultrastructure of the endocrine cells in the cockroach midgut. Biomedical Research, 2(1): 30-44.

PLATZER-SCHULTZ, I. \& WELSCH, U., 1970, Apokrine sekretion der peritrophischen membran von Chironomus thummi piger Str. (Diptera). Z. Zellforsch. Mikrosk. Anat., 104: 530-540.

PRIESTER, W., 1971, Ultrastructure of the midgut epithelial cells in the fly Calliphora erythrocephala. J. Ultrastr. Res., 36: 783-805.

RAES, H. \& VERBEKE, M., 1994, Light and electron microscopical study of two types of endocrines cell in the midgut of the adult worker honeybee (Apis mellifera). Tissue Cell, 26(2): 223-230.

REINHARDT, C. H., 1976, Ultrastructural comparison of the midgut epithelia of fleas with different feeding behavior patterns (Xenopsylla cheopis, Echidnophaga gallinacea, Tunga penetrans, Siphonaptera, Pulicidae). Acta Trop., 3: 105-132.

REYNOLDS, E. S., 1963, The use of lead citrate at high $\mathrm{pH}$ as an electron-opaque stain in electron microscopy. J. Cell Biol., 17: 208-212.

SERRÃO, J. E. \& CRUZ-LANDIM, C., 1996, Ultrastructure of midgut endocrine cells in workers of stingless bee (Hymenoptera, Apidae, Meliponinae). Iheringia Série Zoologia, Porto Alegre, 81: 151-156.

STOFFOLANO, J. G., DAI, J. D. \& YIN, C. M., 1989, Ultrastructure of the posterior midgut and posterior midgut endocrine cells in Phormia regina (Meigen) (Diptera: Calliphoridae). Redia, 72: 623-642.

ZITNAN, D., SAMAN, I. \& SEHNAL, F., 1993, Peptidergic innervation and endocrine cells of insect midgut. Arch. Insect. Bioch. Physiol., 22: 113-132. 